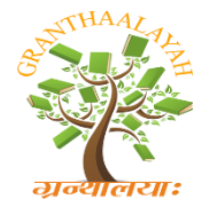

INTERNATIONAL JOURNAL OF RESEARCH GRANTHAALAYAH A knowledge Repository

Management

\title{
DETERMINANTS OF GROWTH OF OFF BALANCE SHEET ACTIVITIES OF PRIVATE SECTOR BANKS: EMPIRICAL EVIDENCE FROM INDIA
}

\author{
Dr. Anil Kumar Swain ${ }^{1}$, Ganesh Prasad Panda *2 \\ ${ }^{1}$ Associate Professor, P.G Department of Commerce, Utkal University, Bhubaneswar, Odisha, \\ India \\ ${ }^{* 2}$ Lecturer in Commerce, Sadhu Goureswar College, Kanikapada, Jajpur - 755011, Odisha, India
}

DOI: https://doi.org/10.29121/granthaalayah.v5.i1.2017.1693

\begin{abstract}
Off-balance sheet activities play a probatory role in helping the banks to hedge their financial assets in the on-balance sheet and enhancing the profitability of the banks. These are mainly the fee based incomes of banks having no or a little investment. Off balance sheet activities are an intriguing part of the financial statements. Presented as footnotes to accounts, these contingent items have an important economic impact that affects the future as well as the current shape of an institution. Off-balance sheet activities also help to improve the commercial banks' scope of operations, and diversification of product lines and earnings. The business of financial intermediaries has witnessed a large increase in the use of off balance sheet activities during the last 40 years. This growth that have come as a response to the need of corporate and firms for different types of guarantees did have a conflicting impact on financial stability and bank soundness. This study is designed to investigate the OBS exposure of Indian Private Sector banks. This study found that CRAR and LT positively affect the OBS activities where as NNPA negatively affects the OBS of private sector banks and there is a relationship of $89 \%$ of net profit with OBS activities of private sector banks.
\end{abstract}

Keywords: Financial Assets; Profitability; Off Balance Sheet Activities; Commercial Banks; CRAR; NNPA.

Cite This Article: Dr. Anil Kumar Swain, and Ganesh Prasad Panda. (2017). "DETERMINANTS OF GROWTH OF OFF BALANCE SHEET ACTIVITIES OF PRIVATE SECTOR BANKS: EMPIRICAL EVIDENCE FROM INDIA.” International Journal of Research - Granthaalayah, 5(1), 61-72. 10.29121/granthaalayah.v5.11.2017.1693.

\section{Introduction}

Banking sector in India plays a crucial role in the Indian economy. It has a significant contribution to the world economy. Indian financial sector is still primarily bank- oriented. So, 
the banking sector represents the most important and significant part of the whole financial sector in India. Indian Financial systems have experienced dramatic changes over the last two decades. The sharp acceleration in the pace of innovation has significantly altered the traditional face of the international financial system also. The risks to global financial stability continued to remain at elevated levels, with global growth witnessing a fragile and multi-paced pattern of recovery. In the meanwhile, the global macro-financial risks shifted from advanced to emerging economies with the latter facing pressures from weakening prospects of growth, falling commodity prices and strengthening of the dollar. Within the emerging world, however, the Indian economy appeared quite resilient, given a modest recovery in the economy, declining inflation and buoyant capital flows that helped in maintaining the external sector balance.

If we see, there is a notable change in the composition of bank businesses and product lines towards non-interest income activities such as off balance sheet activities. Off-balance sheet activities refer to banking products and practices not related to traditional forms of portfolio lending. Off-balance sheet activities are contingent commitments or contracts which generate income to a bank, but are not captured as assets or liabilities under conventional accounting procedure (Nachane and Ghosh 2002). These items are recorded in a bank's accounts as notes to balance sheet. Off-balance sheet activities of commercial banks include guarantees, commitments, market-related activities (financial derivatives), and advisory or management functions. OBS activities include issuing various types of guarantees, like letters of credit, which often have a strong insurance underwriting element, and making future commitments to lend. Both services generate additional fee income for banks. OBS activities also involve engaging in derivatives transactions, such as futures, forwards, options, and swaps. A loan commitment is a contractual commitment to loan a certain maximum amount to a borrower at a given interest rate over some period in the future. Letter of credit is a guarantee that banks sell to underwrite the future performance of the buyers of guarantees. A commercial letter of credit is used mainly to assist a firm in domestic and international trade. The bank's role is to provide a formal guarantee that it will pay for the goods shipped or sold if the buyers of the goods default on its future payments. Standby letters of credit cover contingencies that are potentially more severe, less predictable or frequent, and not necessarily trade related. Loans sold are loans that banks originate and then sell to other investors that (in some cases) can be returned to the originating institution in the future if the credit quality of the loans deteriorates. Derivatives are a position taken in the form of swaps, options, futures, and forwards contracts by the banks for hedging and trading purposes.

\section{Importance of the Topic}

This study is designed to investigate the OBS exposure of Indian private banks. It will identify the ability of these banks to generate fee based income which will neutralize the pressure of earnings income in terms of profit. This study describes empirically the role of OBS in profitability of Indian Private Sector banks. Therefore conducting research in this area will benefit shareholders and stakeholders of the banking sector. The study would have benefit for Management, Government, Investors and practitioners and academicians by providing useful information about the impact of regulation in form of reserve requirement and capital adequacy requirement upon OBS activities of commercial banks. Knowledge of these factors would be useful in helping the regulatory authorities and bank managers formulate future policies aimed at improving the banking service, profitability and structure of the Indian banking sector. By establishing OBS activities and their determinants, 
bank regulators and management can gain better understanding of the issue. This study will help to enrich literatures on the subject matter by providing empirical evidence on the subject. The study could also be used as an initiation for those who are interested to conduct a detailed and comprehensive study regarding the topic. Thus it will serve as a reference for further study on related topics. Therefore, the research on the topic could be of great interest to management, shareholders, as well as for supervisory authorities and researchers and academicians.

\section{Research Gap and Statement of the Problem}

There is a lot of study on off balance sheet items in other countries. But in India there is a very less number of studies that have been made. In these studies also it is observed that most of the studies were relating to off balance sheet items and its impact upon the market risks of the concerned countries. Besides that there was study relating to profitability of banks in relation to OBS activities of banks and whether there is efficiency of banks to generate profit out of OBS activities. So we found a gap between them that no study has not been made about the empirical relationship between Off balance sheet activities and its various determinants like CRAR, NIM, NNPA etc. so by observing this fact, the current study is taken up with the Private sector banks in India for the year 2005-06 to 2014-15.

\section{Objectives of the Study}

1) To understand the conceptual aspects of off balance sheet activities of Commercial banks in India.

2) To study the determinants like CRAR, NNPA, LT, NIM and ROA and their impact on off balance sheet activities of Private sector banks in India.

3) To examine whether there is a relationship between off balance sheet activities and net profit of Indian Private Sector banks.

\section{Hypothesis}

$\mathbf{H}_{1:}$ CRAR positively affects OBS activities of Private sector banks.

$\mathbf{H}_{2:}$ Liquidity to total assets (LT) negatively affects OBS activities of Private sector banks.

$\mathbf{H}_{3}$ : NNPA positively affects OBS activities of Private sector banks.

$\mathbf{H}_{4:}$ NIM negatively affects OBS activities of Private sector banks.

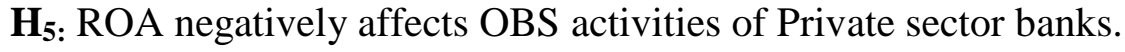

\section{Literature Review}

Hassan (1993) examined the relationship between OBS activities and market risk of large commercial banks of the US. He found that OBS activities contribute to the overall diversification of the bank portfolio risk by reducing the total risk. Nevertheless, OBS items do not influence the systematic risk of banks and this may be due to the fact that OBS items are not a concern of well- diversified stockholders.

Jiakai Chen (2015) studies the interaction between maturity transformation and moral hazard, under the context of banks financing through the off-balance sheet and concluded that regulators 
can eliminate the moral hazard problem by imposing a simple minimum capital ratio requirement.

Chatterjee and Sinha (2005) and Sinha (2005) estimated the efficiency of Indian commercial banks using the data envelopment approach and FDH approaches respectively. They have taken non-interest income out of the output indicators. The results suggest an improvement in performance the existence of considerable gap between public and private sector banks.

Dr. Ram Pratap Sinha (2005) to compare the Indian commercial banks (for the reform period) in respect of their ability to generate income out of off balance sheet activities by using the Data Envelopment Approach and also investigated on the context of a panel data framework, the impact of operating efficiency, capital adequacy and NPA incidence on the risk taking behaviour of the Indian commercial banks the result of his study was that the Private sector commercial banks are lagging behind the private sector commercial banks in terms of off balance sheet activities.

IMF Working Paper (2000) Research Department Pbreuer opined that the simultaneous unwinding if leveraged positions can trigger financial turbulence. Although Balance Sheet measures of leverage are available, it is useful to construct a measure of leverage that incorporates both on and off balance sheet activities. This paper provides measures of leverage implicit in derivative contracts by decomposing the contracts into cash market equivalent components.

Chaudhry (1994) investigated the impact of OBS activities on commercial banks' exposure to market-based risk in the US by utilizing a two-stage model. He found that larger banks are more efficient in interest rate risk management as compared to the smaller ones.

D.M.Nachane and Saibal Ghosh (2007) made an Empirical Analysis of the Off-Balance Sheet Activities of Indian Banks and results show that bank-specific factors, regulatory factors and general macroeconomic conditions-all significantly affect the diffusion process of OBS items in India. In Private sector and foreign banks, bank size seems to impose constraints on engaging in OBS products. The evidence shows significant diseconomies of scope between aggregated OBS 13 items and loans in the new private and foreign bank groups.

A.K. Swain (2008) made an empirical study of Off balance sheet activities of scheduled commercial banks in India from 1997 to 2006 and identified the various determinants of off balance sheet activities and found that there is a positive relation between NIM with the OBS activities and negative relationship with NNPA and CRAR and it is the NNPA which highly influences the OBS activities.

\section{Research Methodology}

The data are basically collected from secondary sources. This secondary source includes mainly Reports on Trends and progress of banking in India from the RBI website. The statistical tables are prepared by compiling data from RBI publications and statistical tables. Besides that we have 
borrowed a lot of things from various Magazines \& journals. Many websites have also been referred for collecting much important information.

The main objective of the study as mentioned earlier to understand the factors driving the OBS activities of Private sector commercial banks and other bank groups. For this purpose an empirical exercise is being carried out by taking cross sectional data for Private sector bank groups from the period 2005-06 to 2014-15 in a multiple linear regression framework. Formally the Econometric Model used is written as follows:

$$
\mathrm{Y}_{\mathrm{i}}=\beta_{\mathrm{i} 0}+\beta_{\mathrm{i} 1} \mathrm{X}_{\mathrm{i} 1}+\beta_{\mathrm{i} 2} \mathrm{X}_{\mathrm{i} 2}+\beta_{\mathrm{i} 3} \mathrm{X}_{\mathrm{i} 3}+\ldots \ldots \ldots+\beta_{\mathrm{ij}} \mathrm{X}_{\mathrm{ij}}+\mathrm{u}_{\mathrm{ij}}
$$

$\mathrm{Y}_{\mathrm{i}}=\mathrm{ith}$ observation of the dependent variable.

$\mathrm{x}_{\mathrm{j}}=$ independent variables. $\mathrm{J}=1,2,3, \ldots \mathrm{k}$.

$\mathrm{x}_{\mathrm{ij}}=\mathrm{ith}$ observation of the $\mathrm{jth}$ independent variables.

$\beta_{\mathrm{i} 0}=$ Intercept term

$\mathrm{u}_{\mathrm{ij}}=$ Residual term/ Error term

\section{Dependent and Independent variables:}

For the purpose of this study two types of variables have been taken they are Dependent variables and Independent variables.

Here $\mathrm{Y}$ is the dependent variable representing OBS activities in terms of total contingent liabilities to total liabilities.

- $\mathrm{X}_{1}$ represents the capital to Risk weighted assets ratio (CRAR).

- $\mathrm{X}_{2}$ represents the ratio of total liquid assets including cash balances, balances with RBI and other banks, money at call and short notice and investment in Govt. and other approved securities as \% of total assets.

- $\mathrm{X}_{3}$ represents the net non- performing assets as \% of total assets (NNPA).

- $\mathrm{X}_{4}$ represents net interest margin which is the difference between interest income and interest expenses as \% to total assets (NIM).

- $\mathrm{X}_{5}$ represents the Return on assets (ROA).

\section{Assumptions of the Model:}

1) Linear regression model, or linear in the parameters.

2) Fixed independent values or independent values independent of the error term i.e. we require zero co variance between $u_{i}$ and each $x$ variables. i.e. $\operatorname{Cov}\left(u_{i} x_{2 i}\right)=\operatorname{Cov}\left(u_{i} x_{3 i}\right)=0$

3) $\mathrm{E}\left(\mathrm{u}_{\mathrm{i}} / \mathrm{x}_{2 \mathrm{i}} \mathrm{x}_{3 \mathrm{i}}\right)=0$ for each $\mathrm{i}$

4) $\operatorname{Var}\left(\mathrm{u}_{\mathrm{i}}\right)=\sigma^{2}$

5) $\operatorname{Cov}\left(u_{i} \quad u_{j}\right)=0 \quad I \neq j$

6) There must be variation in the values of the independent variables.

7) No exact multicollinearity between the independent variables.

8) No. of observations n must be greater than the no. of parameters to be estimated.

9) There is no specification bias.

Besides these tools Carl pearsons co- efficient of correlation and $\mathbf{T}$ - test has been used to test the significance. 


\section{Private Sector Bank in India: A Recapitualisation}

The private-sector banks in India represent part of the Indian banking sector that is made up of both private and public sector banks. The "private-sector banks" are banks where greater parts of stake or equity are held by the private shareholders and not by government.

Banking in India has been dominated by public sector banks since the 1969 when all major banks were nationalised by the Indian government. However, since liberalisation in government banking policy in the 1990s, old and new private sector banks have re-emerged. They have grown faster \& bigger over the two decades since liberalisation using the latest technology, providing contemporary innovations and monetary tools and techniques. ${ }^{[1]}$

The private sector banks are split into two groups by financial regulators in India, old and new. The old private sector banks existed prior to the nationalisation in 1969 and kept their independence because they were either too small or specialist to be included in nationalisation. The new private sector banks are those that have gained their banking license since the liberalisation in the 1990s.

\section{Off Balance Sheet Exposure of Indian Private Sector Banks}

Cut throat competition in the Indian banking industry has posed a lot of risk and threat to the Indian Private Sector banks. Their profit is not increasing up to a global level. So they are going for the off balance sheet activities. Like the Indian Public sector banks they are also doing their business in foreign currency in order to hedge these foreign exchange risks they are going for taking position in the international as well as domestic forward exchange market. This leads to huge amount of off balance sheet activity of them. The following table shows the various components of off balance sheet exposures and its total of Indian private sector banks with money value for different periods.

Table 1: Off balance sheet exposure of private sector banks in India from 2005-06 to 20013

\begin{tabular}{|c|c|c|c|c|c|c|}
\hline & \multicolumn{4}{|c}{ OBS OF PVT BANKS } & \multicolumn{2}{c|}{ (In Crores) } \\
\hline YEAR & FEC & GUARANTEES & EA & TOTAL OBS & OBS OF SCB & $\%$ \\
\hline $2005-06$ & 469954 & 32798 & 350414 & 853166 & 4249342 & 20.08 \\
\hline $2006-07$ & 750792 & 48622 & 530677 & 1330091 & 7656023 & 17.37 \\
\hline $2007-08$ & 1267858 & 74843 & 983619 & 2326320 & 14427369 & 16.12 \\
\hline $2008-09$ & 1016659 & 103906 & 621606 & 1742171 & 11152487 & 15.62 \\
\hline $2009-10$ & 969704 & 132673 & 740221 & 1842598 & 10529958 & 17.50 \\
\hline $2010-11$ & 1125638 & 184441 & 694773 & 2004852 & 13838389 & 14.49 \\
\hline $2011-12$ & 2413700 & 208100 & 165200 & 2787000 & 14594900 & 19.10 \\
\hline $2012-13$ & 1850400 & 238200 & 630800 & 2719400 & 13258300 & 20.51 \\
\hline $2013-14$ & 2293747 & 256323 & 175121 & 2725191 & 13389772 & 20.35 \\
\hline $2014-15$ & 2810894 & 284869 & 198834 & 3294597 & 15013645 & 21.94 \\
\hline
\end{tabular}

Source: RBI, report on trend and progress of banking in India, various years

Source: RBI, report on trend and progress of banking in India, various years and statistical tables relating to banks in India. 
1) FEC: forward exchange contracts

2) EA: Endorsements and Acceptance

It is obvious from the table that from the year 2005-06 to 2006-07 the OBS activities of Private sector banks is showing a positive growth and the growth rate is high in comparison to all the rest 2 components. In 2005- 06 it was Rs. 469954 crores while in 2014-15 it came to Rs. 2810894 crores by increasing around $500 \%$ of the former. It tells that like public sector banks, private sector banks in India also are taking positions in the international markets for hedging the foreign exchange risks. Similarly the guarantees also reflect a positive growth from 32798 Crores in 2005-06 to 284869 Crores in 2014-15. Likewise EA or Endorsements and advances also increasing from Rs. 350414 Crores in 2005-06 to 198834 Crores in the year 2014-15. We can also see from the table that total OBS exposure is increasing and it was the highest in 2014-15 an $\mathrm{d}$ the value is 3294597 crores contributing $21.94 \%$ to the total OBS exposure of the scheduled commercial banks in that year.

The data above may be represented through a chart for better understanding.

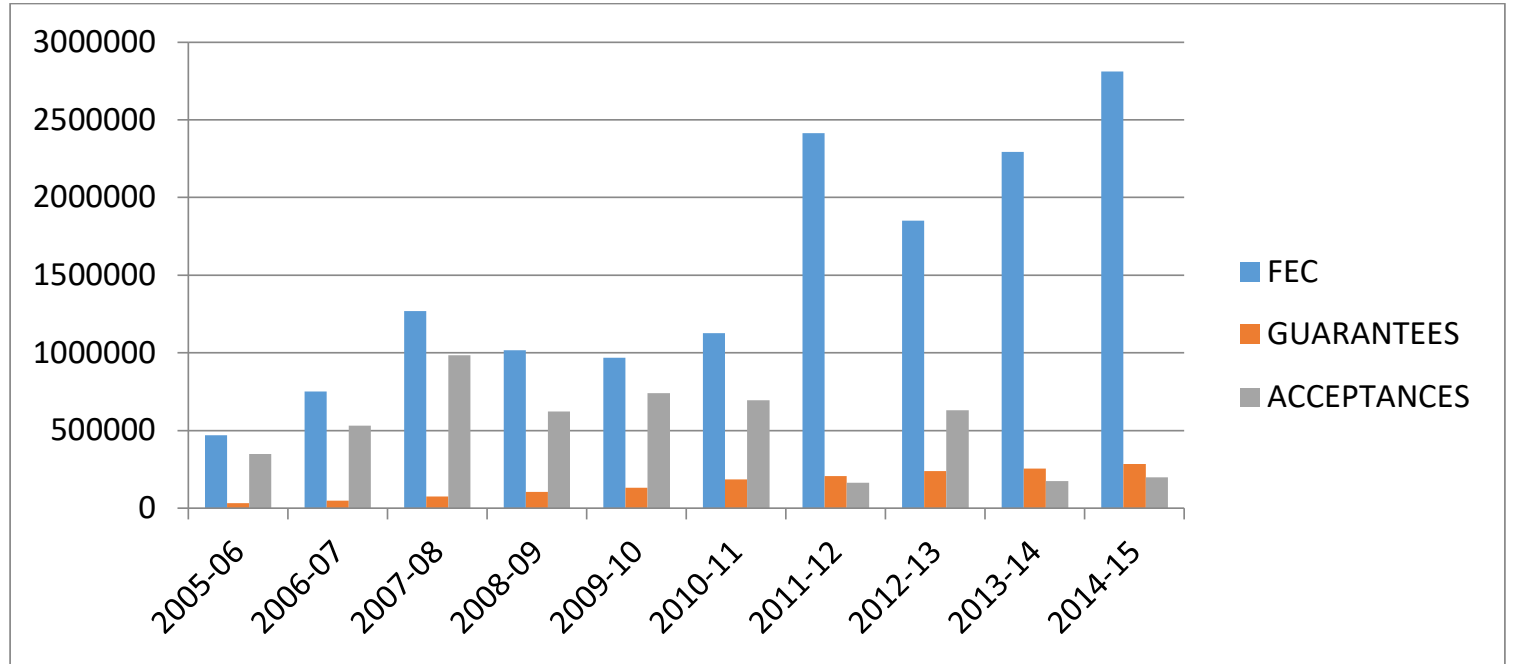

Chart 1: Off balance sheet exposure of private sector banks in India from 2005-06 to 2014-15 Source: self-compiled

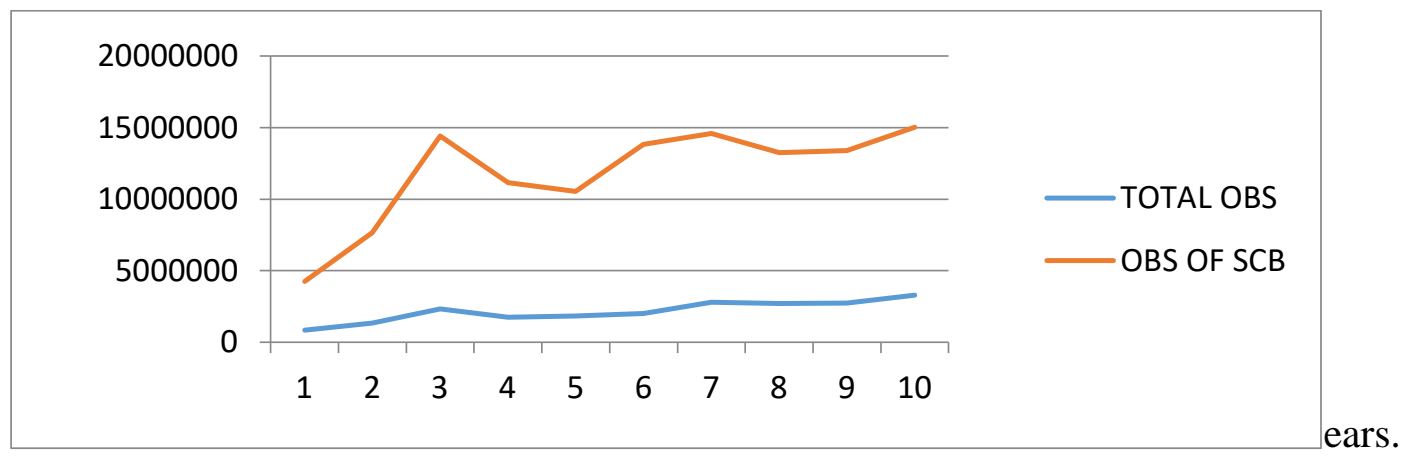

Chart 2: Chart showing the trend of total OBS activities of private sector banks and Scheduled Source: self-compiled commercial banks in India for different years. 


\section{Statistical Data Analysis}

Table 2: Data relating to obs of private sector banks in India from 2005-06 to 2014-15.

\begin{tabular}{|c|c|c|c|c|c|c|}
\hline YEAR & CL & CRAR & LT & NNPA & NIM & ROA \\
\hline $2005-06$ & 149.25 & 12.6 & 39.78 & 0.55 & 2.4 & 1.07 \\
\hline $2006-07$ & 178.43 & 11.99 & 39.28 & 0.54 & 2.45 & 1.02 \\
\hline $2007-08$ & 257.51 & 14.39 & 39.93 & 0.6 & 2.41 & 1.13 \\
\hline $2008-09$ & 169.37 & 15.23 & 85.9 & 0.7 & 2.7 & 1.13 \\
\hline $2009-10$ & 160.13 & 17.43 & 40.71 & 1.04 & 2.9 & 1.28 \\
\hline $2010-11$ & 203.27 & 16.46 & 38.6 & 0.56 & 3.12 & 1.43 \\
\hline $2011-12$ & 164.51 & 16.21 & 37.39 & 0.46 & 3.09 & 1.53 \\
\hline $2012-13$ & 136.67 & 16.84 & 38.1 & 0.52 & 3.22 & 1.63 \\
\hline $2013-14$ & 120.64 & 13.1 & 35.89 & 0.65 & 3.31 & 1.65 \\
\hline $2014-15$ & 127.83 & 15.28 & 44.57 & 0.89 & 3.37 & 1.68 \\
\hline
\end{tabular}

(Source: RBI Reports on Trend and Progress of banking in India, various years.)

Note 1: All \% in the table are calculated by the author taking data from RBI publications For the calculation of regression MS Excel and NCSS software have been used and the result is outlined as under.

Note 2: Before calculating Regression result we go for multicolinearity test and we found that NIM and ROA shows a very high degree of VIF value i.e. > 5\%. So they are excluded and the regression test was rerunned.

\section{The Econometrics Model is written as follows:}

$$
\mathrm{Y}_{\mathrm{i}}=\beta_{\mathrm{i} 0}+\beta_{\mathrm{i} 1} \mathrm{x}_{\mathrm{i} 1}+\beta_{\mathrm{i} 2} \mathrm{X}_{\mathrm{i} 2}+\beta_{\mathrm{i} 3} \mathrm{X}_{\mathrm{i} 3}+\ldots \ldots \ldots+\beta_{\mathrm{ij}} \mathrm{X}_{\mathrm{ij}}+\mathrm{u}_{\mathrm{ij}}
$$

The result now fitted with the model as per the following;

Result:

$C L=166.437+2.083 C R A R+0.184 L T-(59.759) N N P A$

Where $R=0.252$,

$R^{2}=0.063$, adj.

$R^{2}=-0.405$ and

Standard Error of estimate $=47.766$

Complete result of the regression test is represented in the following table.

Table 3: Result of the regression test for private sector banks

\begin{tabular}{|l|l|l|l|l|l|}
\hline & Co efficient & Std. Error & t value & P value & VIF \\
\hline INTERCEPT & 166.437 & 133.527 & 1.246 & 0.259 & \\
\hline CRAR & 2.083 & 8.987 & 0.232 & 0.824 & 1.126 \\
\hline LT & 0.184 & 1.089 & 0.169 & 0.872 & 1.037 \\
\hline
\end{tabular}




\begin{tabular}{|l|l|l|l|l|l|l|}
\hline NNPA & -59.759 & 94.327 & -0.634 & 0.550 & 1.162 \\
\hline ANALYSIS OF VARIANCE & DF & SS & MS & F & P \\
\hline & 3 & 925.406 & 308.469 & 0.708 & 0.58 \\
\hline REGRESSION & 6 & 13689.764 & 2281.627 & & \\
\hline RESIDUAL & 6 & 14615.170 & 2590.096 & & \\
\hline \hline TOTAL & 9 &
\end{tabular}

Note: Value computed by running the regression test with the help of excel and NCSS software and self-analyzed.

\section{Discussion of Result}

For Private sector banks multiple regression runs were undertaken. In the first run Multicolinearity was found and it was removed by removing the variables with high VIF values and finally the result of the run is given above. Our hypothesis regarding CRAR, was there is a positive relationship between CRAR and OBS activities and it is also proven in the above test. So this hypothesis holds true and hence accepted. This means when Private sector banks have an adequate CRAR ratio they can go for more OBS activities and avoid OBS activities in the reverse case.

In case of LT i.e. liquidity to total assets our hypothesis was that LT negatively affects OBS of private sector banks. That means Private sector banks go for OBS exposures at times also when their liquidity position is good and vice versa. Hence in this case also our hypothesis is rejected for LT. The result in this case is like public sector banks proved before.

In case of NNPA, the relationship is found to be negative against our hypothesis that it affects positively the OBS of banks. That means banks are not going to expose themselves towards OBS activities even if they have high NNPA ratio and vice versa is the case.

\section{Analysis of Profit and OBS}

As we know that private banks basically interested to earn profit from their business. In case of loss or a negative trend of profit or in case the rate of increasing profit is low, they want to neutralize these problems by entering into certain fee based activities. As a result of which they go for Forward exchange contracts, endorsements and acceptances and other fee based income. So we may say that there is some sort of relationship between the OBS exposure and Net profit of Private sector banks in India. The following table shows the OBS activities and Net profit of Indian Private Sector banks for different periods. 
Table 4: OBS and Net Profit of Private sector banks in India from 2005-06 to 2014-15 (In crores)

\begin{tabular}{|c|c|c|}
\hline YEAR & OBS & NET PROFIT \\
\hline $2005-06$ & 853166.00 & 4975.00 \\
\hline $2006-07$ & 1330091.00 & 6465.00 \\
\hline $2007-08$ & 2326320.00 & 9521.00 \\
\hline $2008-09$ & 1742171.00 & 10868.00 \\
\hline $2009-10$ & 1842598.00 & 13112.00 \\
\hline $2010-11$ & 2004852.00 & 17712.00 \\
\hline $2011-12$ & 2787000.00 & 22718.00 \\
\hline $2012-13$ & 2719400.00 & 28995.00 \\
\hline $2013-14$ & 2725191.00 & 33754.00 \\
\hline $2014-15$ & 3294597.00 & 38735.00 \\
\hline
\end{tabular}

Source: RBI, report on trend and progress of banking in India.

\section{By applying Carl Pearson's Co efficient of correlation;}

The value comes to $\mathbf{0 . 8 9 2 6 8 6}$

$$
\operatorname{Correl}(X, Y)=\frac{\sum(x-\bar{x})(y-\bar{y})}{\sqrt{\sum(x-\bar{x})^{2} \sum(y-\bar{y})^{2}}}
$$

So we can say here that Net profit and and OBS activities are correlated to the extent of $\mathbf{8 9 \%}$.

\section{To know its significance we will apply $\mathrm{T}$ - test.}

$\mathrm{H}_{0}=$ relationship is not significant.

$$
\mathrm{t}=\frac{r}{\sqrt{1-r^{2}}} \times \sqrt{n-2}
$$

$\mathrm{H}_{1}=$ relationship is significant.

Degrees of freedom $=8$

$\alpha=0.05$

by applying t- statistics the value comes to 7.178

Critical value of $\mathrm{t}$ for $\mathrm{V}=8$, and $\alpha=0.05$ in a two tailed test is 1.860

Calculated value $>$ Critical value. Hence null hypothesis is rejected so the relationship between OBS and Net Profit of private sector bank in India is significant.

\section{Research Findings}

1) Off balance sheet activities are non-interest income activities concerned with FECs, Endorsements and advances and guarantees.

2) OBS activities has both risk reducing as well as risk increasing attributes and the net impact of the risk will depend on the ability to manage the risk from engaging in these activities.

3) Forward exchange contracts are the major component of OBS of Indian Scheduled commercial banks by having the highest amount of exposure. 
4) All the components of OBS are showing a positive trend whereas contribution of Forward exchange contract is more.

5) In case of private sector banks, CRAR and LT positively affects the OBS activities where as NNPA negatively affects the OBS of private sector banks.

6) That means private banks are not going to expose themselves towards OBS activities even if they have high NNPA ratio and vice versa is the case.

7) There is a relationship of $89 \%$ of net profit with OBS activities of private sector banks.

\section{Suggestions}

1) Indian Private Sector banks should go for more forward exchange contracts as they have a huge competition from the foreign players.

2) As off balance sheet activity is a double edged weapon and it has the capacity to both reduce and enhance risk, so Private banks should consider both pros and cons of off balance sheet activities while going for that.

3) Besides traditional instruments private banks should go for inventing new instruments from where they can earn fee based income.

\section{Conclusion}

Indian banking industry has undergone with a new era, where Private sector banks plays a very crucial role in the lifeline of the country but in the same time they are being posed with various types of risks. So OBS activities are now regarded as a better way to check out the losses and to arrest the competition. But this also creates risk with the bank. So the banks need to be alert every time and evaluate the pros and cons before going for Off balance sheet activities.

This paper summarised the various determinants of off balance sheet activities of Indian Private sector banks in an empirical manner and found the determinants and their nature of effect to the off balance sheet activities. The purpose of this paper is to investigate the relationship between off-balance sheet items and the profitability of Indian banking sector also. Off-balance sheet items include traditional (standard) off-balance sheet bank obligations with derivative financial instruments. The most significant off-balance sheet items in Indian banking sector in the period from 2005 to 2015 are forward exchange contracts, guarantees, revolving credits and other lines of credits and financing obligations. In this research paper, the relationship between net profit and off balance sheet activities were tested and found significant and a positive relationship. Our results, consistent with recent research, reveal that bank's regulations do not explain much of the reasons behind the increasing use of these OBS activities, both guarantees and derivatives.

\section{References}

[1] Angelidis, D. \& Lyroudi, K. (2005) "The Magnitude of Off Balance Sheet Activities for The Evaluation Of Banking Productivity," working paper, presented at the International Conference on Finance Copenhagen-Denmark, September 2-4.

[2] Altunbas, Y. \& Chakravarty, S. (2001) "Frontier cost functions and bank efficiency," Economics Letters, vol. 72(2), August, p. 233-240.

[3] Altunbas, Y., Gardener, E., Molyneux, P. \& Moore, B. (2001) "Efficiency in European banking,". 
[4] Agusman, A., Monroe, G., Gasborro, D. \& Zumwalt J. (2008) "Accounting and capital market measures of risk: evidence from Asian banks during 1998-2003," Journal of Banking and Finance, vol. 32(4), April, p. 480-488.

[5] Berger, A. \& Udell, G. (1990) "Collateral, Loan Quality, and Bank Risk," Journal of Monetary Economics, vol. 25(1), January, p. 21-42.

[6] Boot, A. \& Thakor, A. (1991) "Off-balance sheet liabilities, deposit insurance and capital regulation," Journal of Banking and Finance, vol. 15 (4-5), September, p. 825-846.

[7] Chaudhry M K (1994), "Commercial Bank's Off-Balance Sheet Activities and Their Relationship with Market-Based Risk Measures", 4th AFIR International Colloquium, Orlando, pp. 1241-1274.

[8] Hassan, K., Lai, V. \& Yu, M. (2002) "Market Discipline of the Canadian Bank's Letters of Credit ctivities: An Empirical Examination," The Service Industries Journal, Vol. 22(4), September, p. 187- 208.

[9] Hryckiewicz, A. \& Kowalewski, O. (2010) "Economic determinates, financial crisis and entry modes of foreign banks into emerging markets," Emerging Markets review, vol. 11(3), September, p. 205-228.

[10] Ketz, J.E. (2003), Hidden Financial Risk: Understanding Off-balance Sheet Accounting, Wiley, New York, NY, August.

[11] Ketz, J.E. (2006a), "Debunking the supposed link between rules and accounting scandals", SmartPros, available at: http://accounting.smartpros.com/x51840.xml (accessed October 12, 2006).

[12] Swain, Anil kumar (2006): "An Empirical analysis of Off balance sheet activities of scheduled commercial banks in India", The Utkal business Review, 01, p 1-15.

*Corresponding author.

E-mail address: gpanda673@gmail.com 